\title{
Greg Simon
}

Charismatic FasterCures president Greg Simon is on a mission to galvanize US biomedical research-and he's starting by changing attitudes to the sharing of donated patient materials.

Three hours spent with prostate cancer activist Mike Milken was all Greg Simon needed to abandon his own consulting firm and take on the quest of changing the way the US conducts medical research. Milken convinced Simon to head his newly minted, non-profit group designed to accelerate medical solutions by covering a huge array of issues including biotech, computing, informatics, ethics, genetics, medical practice, education, clinical trials and biobanking. With more than a decade of government experience-including a stint as the chief domestic policy advisor to Vice President Al Gore-Simon thought he'd had enough of public service, but Milken's big agenda was too tantalizing to refuse.

Four years later and Greg Simon is in the thick of it. Washington, DC-based FasterCures has secured grants from the Robert Wood Johnson Foundation in Princeton, New Jersey, the Bill \& Melinda Gates Foundation in Seattle and, most recently, the Sumner M. Redstone Charitable Foundation in Beverly Hills, California. Although FasterCures runs a network of 30 non-profit disease research organizations, it is not a grant-making entity. Notes Simon, "The questions are: how do we use the millions we've raised to move billions more by affecting the market, and how do we show the research community how to spend their money in more productive, innovative ways?"

One answer, he ventures, is to encourage people to donate tissue and blood for the advancement of science and to have hospitals and universities share the knowledge derived from those samples with the larger medical community at no cost. "If the patient gives permission for their material to be shared, the biggest obstacle tends to be the university tech transfer offices who view all this tissue as a source of revenue-not because they have made something valuable from it, but because they might," contends Simon. "They treat it like a lottery ticket instead of what it really is - a mutual fund that everyone should share in."

Sandra Shotwell, managing partner at Portland, Oregon-based Alta Biomedical Group, disagrees. Starting out at Stanford University's Joint Research Center in Europe during the late 1980s and later running a public university tech transfer and grants program, Shotwell believes that patients ultimately benefit from programs that identify commercially valuable discoveries and protect them. She points out that in areas of the world in which there is no tech transfer infrastructure, healthcare is often lacking.

"Building confidence in the research and government institutions and their ability to conduct business is critical to the advancement of better healthcare products," says Shotwell. "It makes sense for universities to be able to benefit from the successes to keep their front end of the product development pipeline open."

David Agus, an oncologist and research director for the Prostate Cancer Center at Cedars-Sinai Medical Center in Los Angeles, agrees that intellectual property can help hospitals and academic institutions bolster their bottom lines, but he says that "patients are volunteering to be healed and giving their tissue and information for the cure of their own disease, potentially. We have to respect that and move toward developing national repositories."

But building national repositories is no small endeavor.

"You don't just buy a freezer and stuff your material into it," says
John Mills, CEO of Indianapolis-based BioStorage Technologies, which offers space for a range of specimens, along with inventory management logistics. "A biofacility has to be secure, with an IT system, back-up, emergency systems, air conditioning and proximity to a major airport," he explains. "If we are not storing scientific samples to the highest standard, then we are breeching the ethical trust put in us by the patient."

That ethical trust starts with informed consent, and Simon has experience there, too. In 1986, Simon, who earned his law degree at the University of Washington in Seattle, was the general counsel of the subcommittee in Congress that held a hearing on the case of John Moore.

John Moore was a hairy cell leukemia patient whose $\mathrm{T}$ cells were immortalized by his physician, David Golde, into a cell line that was patented (US patent 4,438,032). Golde continued to draw Moore's blood during follow-up visits, but never revealed his commercial activities. After Moore became suspicious, he sued for a commercial interest in the licensing company, Cambridge, Massachusetts-based Genetics Institute. The California Supreme Court ruled that Moore had no rights in the company, but that he'd been wronged because he was never told what his cells were being used for.

"Some say that
privacy and the right
to profit is more
important than
research, but I could
not disagree more,"
says Simon.

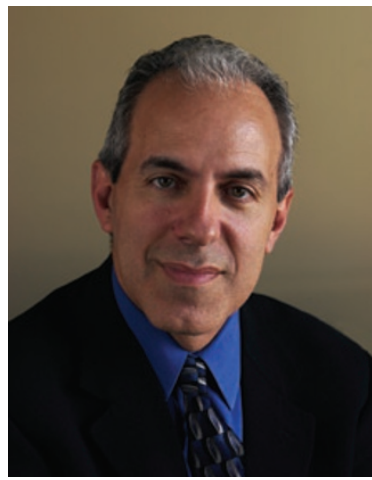

"It's years later, and we are still debating," says Simon. "Some say that privacy and the right to profit is more important than research, but I could not disagree more. If we had commercial rights for every donor of tissue and blood, we wouldn't have a research system that could function. Furthermore, terminally ill people are not nearly as worried about their privacy as they are about their cure."

There are other impediments to bettering research. Simon argues that the pathways for collaborative projects are not in place. "We don't have agreements between one institution and another," he says. "We don't have standards for how tissue is gathered, stored and shared. We don't have protocols for a researcher from one organization to access tissue from another one."

All of which gives Simon and FasterCures plenty to do. In May, the non-profit released a report on clinical trials recruitment and retention, and in June, Simon was appointed to the Google Health Advisory Council. He pledges to continue to empower the human element of research.

"Greg Simon is our hero," Agus says. "Everyone else is pushing a disease, a cause...something they are passionate about. Simon is just pushing for progress, and that is so unusual."

Crispin Littlehales, Covelo, California 